Editorial

\title{
Acknowledgment to Reviewers of Sexes in 2021
}

\section{Sexes Editorial Office}

Citation: Sexes Editorial Office. Acknowledgment to Reviewers of Sexes in 2021. Sexes 2022, 3, 97. https://doi.org/10.3390/sexes3010008

Published: 29 January 2022

Publisher's Note: MDPI stays neutral with regard to jurisdictional claims in published maps and institutional affiliations.

Copyright: (c) 2022 by the authors. Submitted for possible open access publication under the terms and conditions of the Creative Commons Attribution (CC BY) license (https://creativecommons.org/licenses/by/4.0/).

MDPI AG, St. Alban-Anlage 66, 4052 Basel, Switzerland

Rigorous peer-reviews are the basis of high-quality academic publishing. Due to the great efforts of our reviewers, Sexes was able to maintain its standards for the high quality of its published papers. Thanks to the contribution of our reviewers, in 2021, the median time to first decision was 22 days and the median time to publication was 48 days. The editors would like to extend their gratitude and recognition to the following reviewers for their precious time and dedication, regardless of whether the papers they reviewed were finally published:

Alexei, Anisin

Antonogeorgos, George

Baile Ayensa, José Ignacio

Bennachie, Calum

Boggiano, Victoria L.

Brents, Barb

Britt-Rankin, Jo

Chavanelle, Vivien

Collini, Federica

Crespo López, María

De Almeida Kiguti, Luiz Ricardo

Del Río, F. Javier

Dempsey, Robert C.

Di Grazia, Massimo

Diolaiuti, Francesca

Döring, Nicola

Fernández-Fuertes, Andrés A.

Finelli, Carmine

Fisher, Alessandra Daphne

Galazzi, Elena

Garcia, Michelle

Gentil, Paulo

Guttmacher, Sally

Haviland, Kelly S.

Hwang, Merose

Imam, Tasadduq

Jahangir, Yamin Tauseef

Jannini, Emmanuele A.

Jiang, Hong

Keene, Lance

Konishi, Shoko

Lamarche, Veronica

Lee, Liza

Li, Wei
Li, Yachao

López Rodríguez, Marta Sofía

Magano, Olga

Mauerer, Gerlinde

Mcgrath, Shelly

Melendez, Rita

Menih, Helena

Minichiello, Victor

Mohamad, Maznah Binti

Molla Esparza, Cristian

Myszkowska-Ryciak, Joanna

Nacif Antunes, Michele

Navarro, Raul

Navarro-Pérez, Carmen F.

Oliveira-Filho, Aldemir B.

Ortiz-Tallo, Margarita

Pasek, Małgorzata

Peixoto, Maria Manuela

Peña Axt, Juan Carlos

Pereira, Henrique

Petriczko, Elżbieta

Poole, Jay

Quam-Wickham, Nancy

Saneleuterio, Elia

Schumm, Walter R.

Sierra, Juan Carlos

Sirignano, Ascanio

Tan, Kyle K. H.

Townes, Ashley

Tremolada, Marta

Valenzuela, Rodrigo

Van Gulik, Léon

Zaia, Victor 